\title{
They don't live forever: How life history data and encounter probability help to assess success of Muscardinus avellanarius translocations (Rodentia: Gliridae)
}

Nežijí věčně: Jak biologické údaje a pravděpodobnost nálezu pomohou úspěchu vysazování plšíka lískového (Muscardinus avellanarius) (Rodentia: Gliridae)

Sarah BEER ${ }^{1}$, Sven BÜCHNER ${ }^{2,3}$ \& Johannes LANG ${ }^{4,5}$

${ }^{1}$ University of Applied Sciences Weihenstephan-Triesdorf, Am Hofgarten 4, D-85354 Freising, Germany; sarah.beer@t-online.de

${ }^{2}$ Consultancy for Nature Conservation, Ortsstraße 174, D-02829 Markersdorf, Germany; muscardinus@gmx.net

${ }^{3}$ Senckenberg Museum für Naturkunde Görlitz, Postfach 300 154, D-02806 Görlitz, Germany;

${ }^{4}$ Clinic for birds, reptiles, amphibians and fish, Justus-Liebig-University Giessen, Frankfurter Straße 91-93, D-35392 Giessen, Germany; johannes.lang@vetmed.uni-giessen.de

${ }^{5}$ Institute for Animal Ecology and Nature Education, Hauptstraße 30, D-35321 Laubach, Germany

received on 2 February 2018

\begin{abstract}
The hazel dormouse (Muscardinus avellanarius) is a European Protected Species and for this reason, hazel dormice are protected from deliberate killing, injury or disturbance and its sites and resting places are also protected. During development projects impacts on hazel dormouse individuals and populations should be avoided. If avoidance is not possible measures of mitigation and compensation have to be implemented. In many cases the only suitable measure to prevent disturbance, killing or injury of individuals is the translocation of hazel dormice to another suitable habitat. The success of translocations has so far been rarely documented. To assess the success of translocations, the natural mortality of hazel dormice has to be considered as well as the likelihood of finding specific individuals during the proposed action. How these data affect the assessment of translocation success is calculated based on published data on seasonal survival rates of different cohorts and of unpublished monthly encounter probabilities of a population of marked animals. Depending on the time between the translocation event and the subsequent monitoring controls the number of hazel dormice likely to be alive can be low. For this reason, success cannot be evaluated with our method if the sample size is too small.
\end{abstract}

Key words. Muscardinus avellanarius, translocation, mitigation, survival, life history.

\section{INTRODUCTION}

The hazel dormouse (Muscardinus avellanarius) is a European Protected Species and listed in Annex IV of the 1992 European Union (EU) Directive 92/43 on the Conservation of Natural Habitats and of Wild Fauna and Flora (Habitats Directive). Therefore, individual hazel dormice

This contribution has been presented at the 10th International Dormouse Conference held at the University of Liège, Belgium, on 11-15 September 2017 
are protected from deliberate killing, injury or disturbance, and also their breeding sites and resting places are protected and it is forbidden to destroy them. During development projects in dormouse habitats, the possible impact of the project on hazel dormice has to be assessed and appropriate mitigation measures have to be taken to avoid the deliberate killing or injury of dormice. In general, this can be done in different ways (BRIGHT et al. 2006). The first possibility is to make the affected place unattractive, so that they move to adjoining areas by themselves (persuasion). The second option is to translocate them by catching and releasing them in other suitable habitats (translocation). In the course of a translocation hazel dormice are usually captured in nestboxes in which they are transported to a suitable release site (recommendations in BRIGHT et al. 2006).

Both, persuasion and translocation of hazel dormice can negatively affect the animals and may, for example, lead to increased mortality and therefore hamper the intended effect of a mitigation measure (BRIGHT \& MorRIS 1994).

The success of a mitigation measure can be evaluated on two different scales:

(1) on the individual level: the fate of animals can be followed by extensive capture-mark-recapture or telemetry studies (e.g. BRIGHT \& MORRIS 1994);

(2) on the population level: the size and structure of the translocated group and/or the population at the translocation site can be investigated.

Natural mortality and recapture probabilities have to be taken into account when evaluating the success of a translocation by comparing the number of translocated animals with the number recaptured on the translocation site after the translocation. This applies regardless of the evaluation aims at the individual or the population level. It has to be evaluated whether the number of animals encountered at a certain time after a translocation refers to translocation induced mortality or to natural mortality. For this reason, operational data on survival rates and recapture probabilities have to be known as a basis for every evaluation.

In this paper we present a simple model based on published and unpublished life history data that can easily be applied to assess the success of translocation projects.

\section{MATERIAL AND METHODS}

\section{Survival rates}

Survival rates used in this model (Table 1) were calculated using the results from a long-term study in Lithuania (BIEBER et al. 2012). The Lithuanian study site is situated at the north eastern edge of the hazel dormouse range. The climate is continental and the population studied occupies a large mixed woodland (see JuŠKAITIS 2014). Although the data represent a local situation that may differ from the situation in other parts of the hazel dormouse range, the long-term nature of the study is a positive aspect regarding the applicability of the results. In the study by BIEBER et al. (2012) survival probabilities of an individual were influenced by its age ("adult" or "juvenile"), the time of the year it was born ("early" in May-June or "late" in August-September), the season ("month") and its gender ("male" or "female"). Average monthly survival probabilities used in our simple model were calculated for "adults" (mean value for early and late born males and females), "early born juveniles" (mean value for males and females in their first year born between May and June), "late born juveniles" (mean value for males and females in their first year born between August and September) and for four different "seasons" (first two months after weaning, early active season from May until July, late active season from August until September for adults and until October for juveniles, during hibernation from October until April for adults and from November until April for juveniles). 
Table 1. Average monthly survival probabilities of adult and juvenile hazel dormice in different seasons (mean with minimum and maximum values; cf. BIEBER et al. 2012)

Tab. 1. Průměrná měsíční pravděpodobnost přežívání dospělých a juvenilních plšíků lískových v různých částech roku (průměr s minimální a maximální hodnotou; cf. BIEBER et al. 2012)

\begin{tabular}{lccc}
\hline age group / věková skupina & $\begin{array}{c}\text { adults / } \\
\text { dospělí }\end{array}$ & $\begin{array}{c}\text { juveniles / } \\
\text { mlád’ata }\end{array}$ \\
& & $\begin{array}{c}\text { early born / } \\
\text { časně rozená }\end{array}$ & $\begin{array}{c}\text { late born / } \\
\text { pozdě rozená }\end{array}$ \\
\hline first two months after weaning & - & 0.65 & 0.62 \\
/ první dva měsíce po odstavení & - & $(0.61-0.69)$ & $(0.58-0.65)$ \\
early active season (May-July) & 0.82 & 0.65 & - \\
/ časné období aktivity (květen-červenec) & $(0.75-0.88)$ & $(0.61-0.68)$ & - \\
late active season (August-September/October) & 0.92 & 0.86 & 0.62 \\
/ pozdní období aktivity (srpen-záŕŕř́ijen) & $(0.88-0.95)$ & $(0.84-0.87)$ & $(0.58-0.65)$ \\
during hibernation (October/November-April) & 0.97 & 0.93 & 0.84 \\
/ během zimního spánku (ř́íjen/listopad-duben) & $(0.96-0.98)$ & $(0.91-0.94)$ & $(0.81-0.87)$ \\
\hline
\end{tabular}

In practice, juveniles depending on their mother will not be translocated. Therefore, the prediction of survival probability in the model only starts one month after the date of birth of the juveniles. For an easier calculation, the model assumes that all early born juveniles are born at the beginning of June and that all late born juveniles are born at the beginning of August.

Hibernation at the study site lasted from September/October until April/May (BIEBER et al. 2012). In the model, the hibernation of all adults lasts from 1 October until 30 April, whereas the hibernation of the young-of-the-year lasts from 1 November to 30 April. The early active season was defined to last from 1 May until 31 July and therefore, the late active season lasted from 1 August until 30 September for adults and 31 October for juveniles.

It was assumed, that all animals were translocated at the end of a month, so that the first required survival rate is the one of the month following the translocation.

On this basis monthly survival rates can easily be calculated:

$\mathrm{N}_{\mathrm{r}}=\mathrm{N}_{\mathrm{m}} * \varphi_{\mathrm{m}+1} * \varphi_{\mathrm{m}+2} * \varphi_{\mathrm{m}+3} * \ldots * \varphi_{\mathrm{c}-1}$

$\mathrm{N}_{\mathrm{r}}=$ Number of dormice remaining when the control is carried out; $\mathrm{N}=$ Number of dormice of one group (adult or young), caught and translocated at the end of a month; $\mathrm{m}=$ month of capture; $\mathrm{c}=$ month of control; $\varphi=$ average monthly survival probability

\section{Recapture probabilities}

Different studies indicate that $95 \%$ of the local dormouse population can be recorded by conducting regular nestbox checks every two weeks (MorRIs et al. 1990, JUŠKAITIS 1997, BüCHNER 1998).

Recapture probabilities used in our model were calculated on the basis of data from a dormouse study in Saxony (Germany), where animals were individually marked with ear tattoos and nestboxes checked every two weeks between April and November 2012 (seventeen times a year; BöHME 2013). The nestbox density was approximately seven per hectare.

In total, 24 different individuals were captured from April 2012 until November 2012. Four of them were considered to be young-of-the-year. One of the adults was captured only once during an additional 
Table 2. Average monthly recapture probability (AMRP) of adult hazel dormice in nestboxes at a study site in Germany in 2012

Tab. 2. Průměrná měsíční pravděpodobnost zpětného odchytu (AMRP) dospělého plšíka lískového v hnízdní budce na studijní lokalitě v Německu v roce 2012

\begin{tabular}{lccccccc}
\hline month / měsíc & IV & V & VI & VII & VIII & IX & X \\
\hline AMRP $(\%)$ & 22.5 & 45.0 & 47.5 & 25.0 & 11.7 & 10.0 & 27.5 \\
\hline
\end{tabular}

check in between a normal two-week capture period. By pretending that the boxes were only checked every two weeks, this one adult was treated as if it had never been captured. According to the $95 \%$-rule mentioned above, 20 adult hazel dormice lived in the area at the beginning of the capture period and 19 of them were captured. During this study the average recapture probability was highest in June but also high in May and October (Table 2).

\section{RESULTS}

\section{Survival rates}

Average monthly survival rates were used to calculate the number of surviving animals during the active season for adult and juvenile hazel dormice respectively (Fig. 1).

The survival rates can also be applied to a translocation where different numbers of animals of different ages are translocated in different months.

Theoretical example: In total eleven hazel dormice are translocated during different months. Five adult hazel dormice are translocated at the end of May, three juveniles (born on 1 June) are translocated at the end of July and three more adults are translocated at the end of September. The control takes place on 1 June the following year. After considering natural mortality only 4.5 animals can be expected to be still alive when the control is conducted (Table 3 ).

Table 3. Change in the number of translocated hazel dormice when calculated with the average monthly survival probability

Tab. 3. Změna v počtu přesídlených plšíků lískových se započtenou průměrnou měsíční pravděpodobností přežívání

\begin{tabular}{|c|c|c|c|c|c|c|c|c|c|c|c|c|c|}
\hline $\begin{array}{l}\text { year / rok } \\
\text { month / měsíc }\end{array}$ & $\begin{array}{c}1 \\
\text { VI }\end{array}$ & VII & VIII & IX & $X$ & XI & XII & $\begin{array}{l}2 \\
\mathrm{I}\end{array}$ & II & III & IV & $\mathrm{V}$ & VI \\
\hline $\begin{array}{l}\text { number of hazel } \\
\text { dormice translocated } \\
\text { / počet přesídlených } \\
\text { plšíků }\end{array}$ & 5 & 0 & 3 & 0 & 3 & 0 & 0 & 0 & 0 & 0 & 0 & 0 & 0 \\
\hline $\begin{array}{l}\text { mean number of } \\
\text { individuals alive at } \\
\text { translocation site } \\
\text { / průměrný počet } \\
\text { přežívajících jedinců } \\
\text { na lokalitě }\end{array}$ & 5 & 4.1 & 6.4 & 5.1 & 7.5 & 7 & 6.7 & 6.4 & 6.2 & 5.9 & 5.8 & 5.5 & 4.5 \\
\hline
\end{tabular}




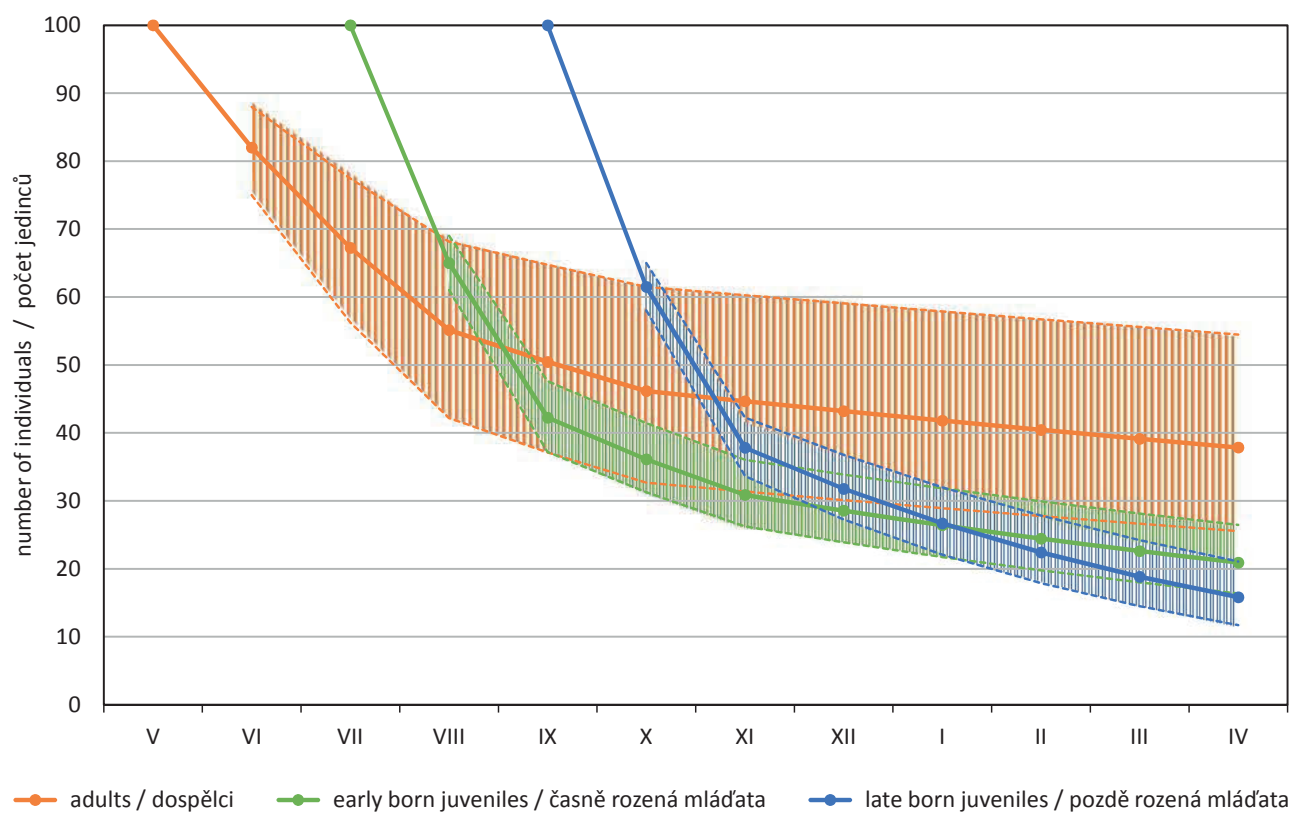

Fig. 1. Decrease in the number of hazel dormice in the course of the year when considering monthly survival rates (see Table 1). The figure shows the average number of the remaining individuals with a minimum and maximum number (considering 95\% lower and upper confidence intervals from Table 1). The early born were all born at the beginning of June and the late born were all born at the beginning of August. Obr. 1. Snižování počtu plšíků lískových v průběhu roku vzhledem k měsíčnímu stupni přežívání (viz tab. 1). Graf znázorňuje průměrný počet zbývajících jedinců s minimálním a maximálním počtem (včetně $95 \%$ dolního a horního intervalu spolehlivosti z tab. 1). Časně narození představují všechny narozené k začátku května, zatímco pozdě narození všechny narozené k začátku srpna.

\section{Recapture probabilities}

In addition to the calculated number of surviving animals the recapture probability has to be considered when evaluating the number of animals encountered during a control. Referring to Table 2 and using the example above, only two out of eleven translocated hazel dormice are likely to be encountered during one check in June in the year after the translocation.

\section{DISCUSSION}

Mitigation measures during development projects in hazel dormouse habitats aim to minimize their possible impact on hazel dormice. The success of mitigation measures should be assessed on a regular basis in order to constantly adjust and optimize methods for the benefit of the animals affected. However, evaluating the success of a translocation remains to be a difficult task. This is because the overall natural mortality of hazel dormice over the course of a year is high and translocated animals may die independent from the translocation process. In practice, 
it is not always possible to decide whether the survival of an individual has been affected by the translocation process or not.

Apart from documenting the fate of single individuals with labour intensive methods (e.g. telemetry, BRIGHT \& MoRRIS 1994), other techniques are needed to evaluate the success of translocations as a standard procedure. Such methods are more likely to be implemented, even if they are not only easily applicable but their advantages and disadvantages are known.

Checking nestboxes for animals and their signs is an established and simple method to survey hazel dormouse populations (CHANIN \& GUBERT 2011, Vogel et al. 2012, JUŠKAITIS \& BüCHNER 2013). By checking boxes frequently during the right time of the year, most animals present can be encountered (MorRis et al. 1990, JuŠKAITIS 1997, BüCHNER 1998). Therefore, nest box controls can be a simple basis for an estimation of the success of translocations. But simply comparing the number of translocated animals with the number encountered sometime later on the translocation site has to take into account:

- the number of animals that would have died from natural mortality and

- the probability of encountering the animals living on the translocation site.

By taking live history data from literature and an unpublished study with marked animals we presented a simple model suitable for calculating the number of animals in a population with a known number of animals at the beginning. Since the predictions have been made very cautiously, the survival rates and numbers of individuals may have been underestimated in our model. On the other hand, recapture probabilities, especially in habitats with a high number of natural cavities, may be lower than calculated from our dataset.

Depending on the time between the translocation event and the subsequent controls, the number of hazel dormice likely to be alive can be low. It should also be noted, that survival estimates calculated with MARK (i.e. BIEBER et al. 2012) cannot distinguish between mortality and dispersal. Indeed, it could be suspected that dispersal at the translocation site might be higher than expected in a natural population. Thus, the number of individuals can even be lower than expected when emigration adds losses to the population. For this reason, even if the translocation did not add to natural mortality, success cannot be evaluated with our method if the sample size is too small. The same is true for small study sites.

Distinguishing translocated animals from resident, or recently immigrated individuals, is a critical point in the estimation of survival and therefore the evaluation of a successful translocation. Nevertheless, marking translocated hazel dormice is not always allowed because of animal welfare reasons (at least in Germany). We strongly recommend marking the translocated animals (if not all captured individuals). Obviously, collecting and evaluating this kind of individual (i.e. high-quality) data would make the evaluation easier and additionally be very useful for further studies on conservation issues in hazel dormice (TrouT et al. 2017).

Despites these uncertainties and limitations the model can be used as a guideline along which translocations can be evaluated as possibly successful: if enough (or even more than expected) animals are still encountered after a certain amount of time on a study site spanning several potential dormouse home-ranges.

\section{SOUHRN}

Plšík lískový (Muscardinus avellanarius) je celoevropsky chráněným druhem, a proto je zapovězeno jeho usmrcování, zraňování, jakož i rušení a místa jeho výskytu jsou chráněna. Při uskutečňování projektů hospodářského a stavebního rozvoje by mělo být předcházeno dopadům na populace i na jednotlivce plšíků. Pokud není možno zcela vyloučit vliv na populace plšíků, je potřeba do projektů zahrnout opat- 
ření ke zmírnění vlivu a náležité kompenzace. V řadě př́ípadů se jako jediné vhodné opatření k předejití rušení, usmrcování nebo zranění jedinců ukázalo přemístování plšíků do jiného vhodného prostředí. Úspěch přemist'ovacích projektů byl dosud jen řídce zkoumán a dokumentován. Aby bylo možno zhodnotit úspěšnost přemist'ovacích projektů, je potřeba vzít v úvahu přirozenou úmrtnost plšíků stejně jako pravděpodobnost nalezení konkrétních jedinců během navrhované akce. Jak tyto údaje ovlivňují hodnocení úspěšnosti translokace se počítá na základě zveřejněných údajů o míře sezonního přežívání různých kohort a nepublikovaných pravděpodobností měsíčního setkání populace značených zviŕrat. V závislosti na době mezi přemístěním a následnými kontrolami může být velmi snížen počet plšíků, kteří mohou zůstat naživu. $Z$ tohoto důvodu nelze s pomocí naší metody vyhodnotit úspěch projektu, pokud je velikost přemístěného vzorku př́liš malá.

\section{Acknow ledgements}

We thank J. BöHME for providing us the original data of his Master Thesis. We are especially grateful to C. Bieber for very helpful comments on the original manuscript and to P. Morris for language editing.

\section{REFERENCES}

Bieber C., JušKaitis R., Turbill C. \& Ruf T., 2012: High survival during hibernation affects onset and timing of reproduction. Oecologica, 169: 155-166.

BöHмE J., 2013: Untersuchungen zur Abundanz und weiteren populationsökologischen Parametern der Haselmaus (Muscardinus avellanarius) in einem isolierten Waldstück in der Oberlausitz mithilfe von verschiedenen Erfassungsmethoden [Studies with Different Detection Methods on Abundance and Other Ecological Parameters of the Hazel Dormouse (Muscardinus avellanarius) in an Isolated Woodland of Upper Lusatia]. Unpubl. MSc. Thesis. Universität Zittau/Görlitz, 79 pp (in German).

Bright P. W. \& Morris P. A., 1994: Animal translocation for conservation: performance of dormice in relation to release methods, origin and season. Journal of Applied Ecology, 31: 699-708.

Bright P., Morris P. \& Mitchell-Jones T., 2006: The Dormouse Conservation Handbook. Second Edition. English Nature, Peterborough, 74 pp.

BüCHNER S., 1998: Zur Ökologie der Haselmaus Muscardinus avellanarius (L.) in einer fragmentierten Landschaft der Oberlausitz [On the Ecology of the Hazel Dormouse Muscardinus avellanarius (L.) in a Fragmented Landscape of Upper Lusatia]. Unpubl. MSc. Thesis. Universität Halle/Saale, 64 pp (in German).

Chanin P. \& Gubert L., 2011: Surveying hazel dormice (Muscardinus avellanarius) with tubes and boxes: a comparison. Mammal Notes, 4: 1-6.

JUŠKAITIS R., 1997: Use of nestboxes by the common dormice (Muscardinus avellanarius L.) in Lithuania. Natura Croatica, 6: 177-188.

JušKaitis R., 2014: The Common Dormouse Muscardinus avellanarius: Ecology, Population Structure and Dynamics. Nature Research Center, Vilnius, 196 pp.

JušKaitis R. \& BÜchner S., 2013: The Hazel Dormouse. NBB English Edition, Westarp Wissenschaften, Hohenwarsleben, 173 pp.

Morris P. A., Bright P. W. \& Woods D., 1990: Use of nestboxes by the dormouse (Muscardinus avellanarius). Biological Conservation, 51: 1-13.

Trout R., Brooks S. \& RudLin P., 2017: The advantages of permanent marking, such as microchipping, during long term monitoring of the common dormouse (Muscardinus avellanarius). Apodemus, 14: 19-26.

Vogel P., Wey A. \& Schubnel E., 2012: Evaluation of Muscardinus avellanarius population density by nest box and by trap checking. Peckiana, 8: 141-149. 